\title{
The Implementation of Linguistic Functional Systemic Approach on the Reading Comprehension to Improve Students Reading Ability
}

\author{
Tengku Ratna Soraya ${ }^{1}$, Emzir $^{2}$, and Sabarti Akhadiah ${ }^{3}$ \\ \{trs_luthfi@yahoo.fr ${ }^{1}$, emzir.unj@unj.ac.id, ${ }^{2}$, sabartiakhadiah@yahoo.com ${ }^{3}$ \} \\ Doctoral Candidate in Applied Linguistics, Jakarta State University ${ }^{1}$, Lecturer of Graduate Program \\ of Jakarta State University ${ }^{2,3}$
}

\begin{abstract}
This research is conducted to improve the students reading comprehension ability in French Department of State University of Medan. The specific objective of this research is to improve the process as well as the result ability in reading French texts through the Linguistic Functional Systemic approach. The type of this research is action research, conducted on 48 students of French education in academic year 2014-2015. This action research refers to the cycle of action research of Kemmis and MC Taggart which consist of four steps, planning, acting, observing, and reflecting. The results indicate that the ability of reading comprehension of students for each cycle shows satisfaction. Cylce 1 refers to the aspect lexicogrammar in text, cycle 2 the aspect of discourse semantic, and cycle 3 , the register. This research shows that the linguistic functional systemic approach can be applied as an alternative to improve the students French reading comprehension.
\end{abstract}

Keywords: Linguistic functional systemic, reading comprehension, reading ability.

\section{Introduction}

Reading is an artificial activity, which is an activity that is learned and continues continuously. The results of Prijana and Saefullah's experimental study said that students have reading skills and training that are different from each other. They also have different reading speed. Prijana and Saefullah note that students who have higher academic achievement tend to be faster in their reading time than those with lower academic achievement. Likewise, in terms of intensity of reading activities. Students with better academic achievement turn out to be more frequent in reading than others.

The ability to understand a text is an important thing that must be owned by students who are learning a foreign language, as well as French. Therefore, this is a major concern of the French Language Education Study Program of the Department of Foreign Language Languages and Arts of the State University of Medan, so that in the 2008 competency-based curriculum, reading clump courses are text studies (étude de texte) as one of courses that must be followed by all students who are studying French, in addition to the scope of other reading courses namely compréhension écrite.

Learning text studies (étude de texte) that took place so far used teaching techniques such as lectures, question and answer, and assignments. Learning media that used are include 
magazine and newspaper texts, advertisements, internet, and television. While the approach to the text which is used by asking general questions from the text (Question-Reponse).

Based on the experience and observations of the researcher while being a lecturer in text study courses (étude de texte), students' ability to read texts has not achieved maximum results in accordance with the standards of competency-based curriculum in 2008 and the CECRL (Cadre Européen Commun de Référence pour les Langues). The curriculum that was compiled since 1996 and entered into force in 2000, as a joint European reference frame for language teaching which contains provisions on what needs to be achieved at each stage of French language learning that includes all four language skills, namely: (1) Phase A1 and A2 = base level, (2. Phase B1 and B2 = middle / independent level, and (3) Phase C1 and C2 = advanced level.

The explanation above is also reinforced by the student's final grade data acquisition in the text study course (etude de texte) of the 2013/2014 academic year, where the lowest score was obtained with a range of value between 0-69 as many as two students, the range of value was 70-79 as many as thirteen students, ranging in value from 80 to 89 as many as fifteen students, and no single student received the highest score with a 90-100 score range. Looking at the data above, this condition requires an improvement in the learning process by using a more in-depth approach of reading the text.

The ability to read French text in this study, especially for the sixth semester students is the ability to read the text for the understanding level, meaning that it refers to the CECRL B2 level standard that is students have the ability to read and analyze French texts related to the theme of daily activities, work, expressions of feeling, and expectations in personal letters contained in magazines, newspapers, advertisements, radio. TV5, and film shows.

The LFS approach is used in this study with the assumption that the LFS approach examines the text used as learning material in text study courses (étude de texte). This approach is proven to be able to answer a variety of linguistic problems, both micro and macro..

\section{Theoretical Study}

\subsection{Reading Ability}

The ability according to Poerwadarminta is a capability or skill to do things well and carefully. While reading ability is the ability to understand information provided by other parties through a writing forum. An important point of reading ability is the ability to understand the information provided by the author. In other languages, reading ability is the ability to understand written, implicit or express ideas, and draw conclusions with meaningful interpretations that are not only merely a reading process without understanding the content of the material being read.

\subsection{Definition and Nature of Reading}

The definition of reading has been widely conveyed by experts. Brown for example argues that reading is an interactive process that is present between the reader and the text, and produces a new understanding. While Gipe identifies four dimensions of a reading process, 
namely linguistic processes, cognitive processes, psychological processes (affective), and physiological processes.

The person's reading ability is largely determined by the reading quantity factor. This means that a person's reading skills are strongly influenced by the amount of time spent in carrying out reading activities. The more time spent for reading each day, the higher the level of comprehension or the easier it is to understand a text.

Suyatmi, in this context, explained about the factors that support reading activities, including:

1) Internal factorsinclude: language competence or ability, interest, motivation, perseverance, concentration, health both physically and spiritually, the ability to neutralize points of weakness, having a suitable background of knowledge discipline, sufficient vocabulary mastery and understanding the purpose reading quickly and carefully.

2) External factors include: providing the right reading materials as needed, interesting, and giving rise to preoccupations and prices that can be reached by the wider community. Likewise some elements in reading and the nature of the reading environment (readability factors), environmental situations and conditions that stimulate the emergence of reading preferences, including the provision of conducive learning places, family atmosphere, school environment, community, friends, teachers, and community leaders.

Susilowati in her journals cites Brown's opinion which states that there are two forms of reading learning in the classroom, namely reading aloud (oral reading) and reading with no sound (silent reading). Reading aloud focuses on the learner's ability to pronounce language sounds and often applied to beginner learners for second language. Silent reading is further divided into intensive reading and extensive reading.

\subsection{Text}

Halliday explained that the text is always covered by the context of the situation and culture. The context of the situation is the scope of the entire environment, whether the speech environment (verbal) or the environment in which the text is produced (pronounced or written). After the context of the situation there is a cultural context which includes the text and context of the situation. To understand a text well, it requires an understanding of the context of the situation and cultural context.

In the perspective of Systemic Functional Linguistics, text is a unit of meaning (semantic units) and not a grammatical unit. Text can be realized by various language units, such as sounds, morphemes, words, groups, phrases, clauses, paragraphs, or books. As a unit of meaning, text can be realized by various grammatical units. This means that the text can be in the form of a text(book), paragraph, complex clause, clause, phrase, group, or sound.

A text, if viewed from the manner and purpose of the presentation, is generally divided into five, namely:

a. Narrative text

According to OkkeKusuma, there are four criteria for a narrative text, namely:

(1) There is a series of events. In order to make a story be shaped, there must be a minimum series of events that take place within a certain period of time, so that it can be called a story. This whole series of events are arranged in its function towards a final situation. So, sometimes temporal linearity can cause problems, as seen for example in detective stories. Likewise the stories seen in the fourth criterion, temporal linearity is often overlooked. 
(2) There is a unity of action at least a subject. A story wants at least one figure to be positioned at a certain time. This can unite criteria $a$ and $b$, because the presence of this figure allows for unity of action. Even so, the presence of the character does not mean anything if it is not associated with other story elements, such as a series of events that relate temporally and predicate (narrative) that shows the character.

(3) There is a process. In a story, a unity of action is needed, namely the existence of the initial situation, transformation and the final situation. The meaning of this process allows us to ascertain temporal elements by negating ideas about a series of events that are separated from each other.

(4) There is a causal relationship in a conflict. In a story, the most important thing is not a logical relationship or causal link between functional stories. This causal relationship forms the story frame and story structure. In general, for the authors, an excuse that can be obtained is the cause of an action which in turn also creates another action. So the next till the story finishes. This series of logical relationships determines the story.

b. Argumentative Text

According to Toulmin in Renkema, there are several views regarding the argumentative text, namely:

1. In a argumentative text the most important is not the logical building, but the way in which the argument is built. The argument is the motivation of ideas or claims that are born through another statement (data). The argumentative relationship between claims and data is also called justification or warrant.

2. In a logical perspective, the most important thing in an argument is a way of giving reasons (reasoning) for the validity of an argument, which starts from presenting the premise to drawing conclusions.

3. In a rhetorical perspective, the most important thing in an argumentative text is the technique and its effectiveness for the recipient of the message

4. Conduct argumentative analysis through pragma-dialectical (pragma-dialectic) approach. They argue that the argumentation is composed of pragma, which is part of a discussion forum where participants act together (moves); and dialectic, part of a critical discussion which, together with moves, became a vehicle for eliminating dissent.

5. In the social-psychological approach, the main purpose of argumentative texts, such as discussions, advertisements, and pamphlets, is an invitation for the recipient of the message to participate in thinking about, feeling and doing certain actions. In this approach discussed the problem of attitude as an important determinant of behavior. In advertising, attitude change is very important, becausethe evaluation of the desired product is better.

\section{c. Description text}

Description text is a text that aims to draw, describe, or give something according to what it is. Description text is the result of observations and writer's impressions of the object of observation. If the description is alive, the reader can imagine something described. Of course what is described can be in the form of something real, it can also be fiction.

In the description there are many descriptions part by part. In this type of text, the sequence structure is facultative, that is, to certain limits, the arrangement can be 
exchanged, because the picture is permanent and simultaneous. It can be said that the characteristic of description is spatial relationship (unity of place). This means that the details depicted are related to one another, and do not constitute a scattered picture.

c. Exposition Text.

Exposition text is a text does not focus on time and actor and it is oriented to the subject, and its parts are logically bound. This text is not used to change people's opinions, but to provide knowledge, expand views, or explain a subject matter. That is why this text is often used to display scientific descriptions (eg papers) and the language used is objective language, not subjective language. The characteristic of this text is the existence of a question as the starting point (opening) of the text. This question is not always explicit but can also be implicit. The answer to that question is contained in the overall explanation of the text.

d. Persuasion Text

Persuasion text is a text whose content is solicitation or advice, usually concise and interesting, and aims to strongly influence the readers or listeners to make the advice or invitation.

\subsection{Reading Ability Test}

Iskandarwassid and Sunendar stated that the reading ability test is a test of language skills that can be carried out in language teaching, both in teaching for first language and second language or foreign languages. In line with this opinion, Nugiyantoro stated that the reading ability test aims to measure the learner's ability to find information and understand the content contained in the reading text. Therefore, the reading text that will be tested must contain information that can require the learner to learn in understanding the text.

Reading learning in text study courses (étude de texte) is based on UNIMED assessment with the following categories:

Table 1. Assessment in Text Study Cours

\begin{tabular}{ccc}
\hline No & Score & Category \\
\hline 1. & $90-100$ & Excellent \\
2. & $80-89$ & Good \\
3. & $70-79$ & Fair \\
4. & $0-69$ & Poor \\
\hline
\end{tabular}

\subsection{Systemic Functional Linguistics Approach}

Systemic Functional Linguistic Approach bases its study on two things, namely first having the understanding that the use of language is a semiotic system. As semiotics, language occurs from two elements, namely meaning and expression. The relationship between these two elements is a realization relationship, that is the meaning realized or encoded by expression. One of the characteristics of language as social semiotics is language has a function in a social or functional language context in a social context. In this connection, there are three notions in functional concepts. First, language is structured based on the function of language in human life. In other words, language is structured according to human needs for language. Second, the function of language in human life includes three things, namely 
describing, exchanging, and assembling human experience. These three functions are called language functions. Each function determines the language structure or grammar.

Thus, grammar (lexicogrammar) is a theory of human experience which includes exposure theory, exchange, and organizational meaning. The third definition is each unit of language is functional to a larger unit, in which the unit becomes an element. With this definition, noun groups, verbs, prepositions, inserted clauses, or other units function in their respective tasks to establish clauses. Likewise, clauses have function in complex clauses to build the complex.

The second concept implies that LFS focuses on the study of texts or discourses in a social context, the text is limited as a unit of functional language in a social context. Functional language gives meaning to language users.

Language in social interaction consists of three elements: meaning, form, and expression. The relationship of these three elements can be said as: meaning (semantics or discourse semantics) realized by the form (lexicogrammar) and this form is then encoded by expression (phonology / graphology). In other words, in the LFS view, language consists of three levels, namely semantics, grammar, and phonology / graphology. Semantics is realized by grammar, and then grammar is expressed by phonology (in oral language) and graphology (in written language). The nature of the meaning and form relationship is natural, with the definition of relationship can be referred to the social context, while the meaning and expression relationship is arbitrary.

\section{Research Method}

The research method used in this study is action research by adopting the Kemmis and MC Taggart's action research model which consists of four stages, namely, planning, acting, observing, and reflecting. This study occurs for three cycles in the text study course (étude de texte) for the sixth semester students of the French Language Education Study Program, Foreign Language Education Department, Languages and Arts Faculty, Medan State University (UNIMED).

Data collection techniques carried out in this study include observation which has been done before giving actions and at the time of giving actions. Observation during learning take place based on observation sheets.

While data analysis techniques are carried out through three stages, namely data processing, data exposure, and data conclusions. Data processing is done by grouping data into two groups, namely qualitative data and quantitative data. Quantitative data is analyzed by percentage, then the percentage results are expressed or presented in quantitative sentences. Qualitative data is analyzed by making a score on items that need to be scored. Then percentage, the percentage results are interpreted in the form of quantitative sentences and summarized into descriptive sentence forms.

\section{Result Of The Research}

\subsection{Description of Research Result}

1. The Process of Improving the Reading Ability on French Text through the LFS Approach 
The reading learning process was carried out in three cycles. In the first cycle, the learning objective was so that students could read the lexicogrammar aspect of the text which includes transitivity, Thème and Rhème, and the mood and residue.

In the second cycle, the learning objective was so that students could read the aspect of the discourse semantic in the text which includes complex clauses, conjunctive relationships, anaphore and cataphore, and lexical relations in the text.

Whereas in the third cycle, the learning process of reading French texts discusses the aspect of the register which discusses fields, modes, and tenor in the text.

2. The result of Increasing Reading Ability on French Text through the LFS Approach

The activity which had done before this research was the researcher gave a test of reading French text to students to find out their initial abilities.

Based on the result of the pre-test reading French text, it was known that the lowest score with a score range of 0-69 as many as five (5 students) and the highest score with a score range of $90-100$ of one (1 student).

Based on the results of the pre-test it can be concluded that the ability to read French text in students is still in poor category, this can be seen from the number of students who get a minimum score of 85 in each aspect of the reading ability on French text. This is the basis for implementing actions in the first cycle.

The implementation of the first cycle occurred four times. At the end of the cycle, a test was done for 90 minutes, and the result of the French text-reading ability of students in the first cycle increased when compared with the result of the pre-test, that was the absence of students who received the lowest score with a range of values between $0-69$, while scores 70 79 obtained by 27 students (56.25\%), a score of $80-89$ obtained by 15 students $(31.25 \%$ ), and the highest score with a range of $90-100$ scores obtained by 6 students $(12.50 \%)$. Display of result data from the first cycle score can be seen in the following figure:

Furthermore, the test result of the reading ability on French text in the second cycle has increased compared to the first cycle, that is the absence of students who obtained the lowest score with a score of $0-69$, while the score $70-79$ obtained by $13(27.08 \%)$, a score of $80-89$ was obtained by 28 people $(58.33 \%)$, and the highest score with a $90-100$ score range of 7 people $(14.58 \%)$

In the third cycle, based on the test result, it is known that the ability of students has increased compared to the results of the second cycle. This can be seen from the absence of students who obtained the lowest score with a score of 0-69, while a score of 70-79 obtained by 7 people (14.58\%), a score of $80-89$ obtained by 33 people $(68.75 \%)$, and highest score with a range of $90-100$ obtained by 8 people $(16.67 \%)$.

Based on the data obtained, it can be concluded that the use of the LFS approach to the aspect of speed can improve students' ability to read French text.

Based on the data obtained through this study it can be stated that the improvement in student learning outcomes in reading French texts throughthe LFS approach is very clear at the end of each action that has been carried out.

At the end of the first cycle, the average ability of students was only 79 . The figures or data can be interpreted that in general the ability of students to read French texts in this cycle was included in the sufficient category.

Furthermore, in the second cycle, the average ability of students to read French text has experienced an increase, namely obtaining a score 83 in the good category but not in accordance with the minimum standards that the researcher has determined was 85 .

Furthermore, in the third cycle, the average ability of students to read French text has 
experienced an increase, namely obtaining a score 87 and included in the good category and in accordance with the minimum value standards that researchers have set. Although the average score did not differ too much, but qualitatively the score obtained differed significantly.

\subsection{Discussion}

The discussion on the result of increasing the ability to read French text through the LFS approach was obtained from the results of the tests carried out at the end of each cycle.

Before the implementation of the action, the average ability of students to read French texts was only $16.7 \%$. In the first cycle, the learning outcomes of students in reading French texts showed a mean of $33.3 \%$. This means that the ability of students is categorized into fair criteria when discussing lexicogrammar analysis in the text. Nevertheless, there was an increase in the ability of students to read French texts from pre-test and ability in the first cycle of $16.6 \%$.

In the second cycle, researcher applied semantics discourse analysis, the ability of students increase to $40 \%$. Based on these data it can be concluded that through the implementation of the second cycle by discussing semantics discourse analysis, the ability of students to read French text increased by $23.4 \%$ of the ability of students in the first cycle.

Furthermore, student learning outcomes in the third cycle generally got an average of 86 with good value categories. When viewed from the results of achievements in the third cycle, there was an increase in student learning outcomes by $75 \%$ when applying the register analysis.

Based on the result of these achievements, it can be concluded that the results of reading learning on French text increase significantly from cycle to cycle. When compared with the initial data, data were obtained regarding to the improvement of students' ability to read French texts by $58.3 \%$ when learning was applied through the LFS approach.

From the finding result of the research, it can be said that the formulation of the action research hypothesis, that is "if the LFS approach is applied, then the students' reading ability on French text will be increased."

\section{Conclusion}

Based on the results obtained, it can be concluded: (1) The learning process of reading skills in text study course (étude de texte) with lexicogrammar analysis material (transitivity analysis, thème and rhème analysis, mood and residue analysis), semantic discourse analysis (analysis of complex clauses, conjunctive relationships, lexical relations, and references (anaphore and cataphore), and register analysis (field, mode, and tenor) which have been going on for three cycles have increased students' interest in reading the text. (2) Based on the learning process that has been carried out, the results show that the LFS approach is effectively used to improve the students'reading ability on French text. It can be seen from the percentage of minimum standard score that the researcher has stated that was 85 . In the first cycle, students who were completedas $43.75 \%$ of all students, in the second cycle as $73 \%$, while in the third cycle as $85.42 \%$ of the total number of students had obtained scores according to the standards set. 


\subsection{Implications}

Based on the learning process that has taken place, the results show that the quality of learning and student learning outcomes in text study course (étude de texte) through the LFS approach in each cycle has increased, this shows that the LFS approach can be used as an alternative approach to French language learning in order to improve the quality of students especially in learning reading courses.

The learning process of reading French text skills through the LFS approach begins with reading the text as a whole and then analyzing lexicogrammar aspects (transitivity analysis, thème and rhème analysis, mood and residue analysis), semantics discourse analysis (complex clause analysis, conjunctive relationships, lexical relations, and references (anaphore and cataphore), and register analysis (fields, modes, and tenors. The advantages of this LFS approach compared to other approaches can be seen from the detailed analysis of features that build a text, this makes students better understand the content of text reading However, this approach has weakness in the terms used which must be explained first to the Students in Languages and Arts Faculty French Language Study Program who attend lectures.

\subsection{Suggestion}

Based on the conclusion and implication above, the following suggestion are suggested: (1) Lecturers of French courses are generally expected to be able to understand and to use the LFS approach in the teaching and learning process of French courses in the classroom as in text study course (étude de texte), understanding of writing (compréhensionécrite by selecting LFS discussion according to the situation and condition of the student (débutant, intermédiaire, and avancée) so that the learning objectives to be achieved can be maximized. (2) Lecturers can develop discussion in LFS in accordance with the teaching objectives to be achieved and in accordance with the ability of students by knowing the French language skills of students in the previous semesters before applying the LFS approach. (3) Lecturers and students are expected to be able to dig up information about the LFS approach in French both through books about French teaching as well as through the internet.

\section{References}

[1]Abdurrahman Adisaputra, Linguistik Fungsional Sistemik: Analisis Teks Materi Pembelajaran di Sekolah Dasar (SD), Jurnal Ilmiah Bahasa dan Sastra Volume IV No. 1 April, 2008.

[2]Abdul Azis Faradi, Kajian Modalitas Linguistik Fungsional Sistemik pada Teks Debat CapresCawapres pada Pilpres 2014-2019 dan Relevansinya dengan Pembelajaran Wacana di Sekolah, RETORIKA: Jurnal Ilmu Bahasa, Vol. 1, No. 2 Oktober, h. 236, 2015.

http:// ejournal.warmadewa.ac.id/index.php/jret (diakses 27 Maret 2018)

[3]Amrin Saragih, Bahasa dalam Konteks Sosial: Pendekatan Linguistik Fungsional Sistemik terhadap Tata bahasa dan Wacana. Medan: Pascasarjana Unimed Press, 2006.

[4]Anderson, N, dalam E. Hinkel (Ed), Handbook of Research in Second Language Teaching and Learning (Mahwah, N.J. : L. Erlbaum Associates), 2005.

[5]Broughton [et al] dalam H.G. Tarigan, Membaca sebagai suatu keterampilan berbahasa. (Bandung: Angkasa.), 2015.

[6]Christine Tagliante, L'evaluation, (Cle International, Paris), 1991.

[7]Endang Susilowati,"Penerapan Metode Pembelajaran Think-Pair-Share-Square di Kelas TPB-ITS untuk Meningkatkan Kemampuan Membaca Bahasa Inggris Mahasiswa", Jurnal Sosial Humaniora, Vol 2 No. 2, Nopember.http://iptek.its.ac.id/index.php/ jsh/article/view/659 (diakses 27 Maret 2018) 
[8]Gillian Brown dan George Yule, Discourse Analysis, (Cambridge: Cambridge University Press), 1996.

[9]Halliday \& Hasan, Language, Context, and Text: Aspect of Language in Social-Semiotic Perspective (diterjemahkan ke dalam bahasa Indonesia oelh Asruddin Barori Tou 1992. Bahasa, Konteks, dan Teks: Aspek-Aspek Bahasa dalam Pandangan Semiotik Sosial) Yogyakarta: Gajah Mada University Press), 1985.

[10]_ Cohesion in English, (London: Longman Group Limited), 1992.

Iskandawassid dan Dadang Sunendar, 2013,Strategi Pembelajaran Bahasa, (Bandung: PT. Remaja Rosda Karya).

[11]Jan Renkema Discourse Studies: An Introductory Textbook, (Amsterdam/Philadelphia: John Benjamins Publishing Company), 2004.

[12]M. Cindhy,"Kontribusi Penguasaan Kosakata dan Motifasi Belajar Terhadap Kemampuan Membaca Teks Berbahasa Jerman Terhadap Peserta Didik Kelas XI Program Keahlian Animasi SMK Negeri 5 Yogyakarta Tahun Ajaran 2011/20012”, 2012.

http://eprints,UNY.ac. id/id/eprint/9123. h. 23 (diakses 28 maret 2018)

[13]Sutrisna, Meningkatkan Kemampuan Membaca Kata melalui Metode Suku Kata Bagi Anak Kesulitan Belajar Kelas I SDN 03 Bandar Buat Padang, E_JUPEKhu (Jurnal Ilmiah Pendidikan Khusus) Volume 2 Nomor 3 SeptemberH. 362, 2013.

http://ejournal.unp.ac.id/index.php/jupekhu (diakses 28 Maret 2018)

[14]Suzanne Eggins, An Introduction to Systemic Functional Linguistics (New York: Continum), 2004.

[15]Suharso,"The Validity of Cloze-Test, Test-C and Self Assessment as a Measurement of the Ability to Read English Texts", Jurnal Penelitian dan Evalusai Pendidikan, Nomor 1, h. 104, 2008. http://journal.uny.ac.id/index.php/jpep/article/view/file/1421/1209, (diakses 27 Maret 2018)

[16]Suyatmi, Membaca I (BPK), (Surakarta, UNS Press).

[17]Okke Kusuma Sumantri Zainar dan Ayu Basoeki Harahap, Telaah Wacana, (The Intercultural Institute),. 2009.

[18]Toulmin, seperti ditulis Jan Renkema, Discourse Studies: An Introductory Textbook.(Amsterdam/Philadelphia: John Benjamins Publishing Company), 2004. 